\title{
Current use of live tissue training in trauma: a descriptive systematic review
}

\author{
Luis Teodoro da Luz, MD \\ Bartolomeu Nascimento, MD, MSc \\ Col Homer Tien, MD, MSc \\ Michael J. Kim, MD, MA \\ Avery B. Nathens, MD, PhD \\ Savvas Vlachos, MD \\ Col Elon Glassberg, MD, MHA
}

Accepted for publication

Nov. 18, 2014

Correspondence to:

L.T. da Luz

2075 Bayview Ave. Rm C1.60

Toronto ON M4N 3M5

Iteoluz@yahoo.com

DOI: $10.1503 /$ cjs.014114

\begin{abstract}
Background: Growing public concern for animal welfare, advances in computerized simulation and economic barriers have drawn a critical eye to the use of live tissue training (LTT) in trauma skills acquisition. As a consequence, other simulation methods have replaced LTT, for example, in the Advanced Trauma Life Support (ATLS) course. Owing to the lack of clear conclusions in the literature, we conducted a systematic review to determine the value of LTT alone and in comparison to other simulation methods in trauma.
\end{abstract}

Methods: We performed a systematic review of the literature considering observational studies and randomized controlled trials (RCTs) that examined LTT in trauma exclusively or compared with other simulation methods. Independently and in duplicate, we adjudicated studies for inclusion and data abstraction. We assessed the quality and risk of bias.

Results: Twelve studies met our inclusion criteria: 2 RCTs and 10 prospective cohort studies. Eight and 4 studies were performed in the military and in the civilian settings, respectively. Anesthetized swine were used in 8 studies and goats in 1 . The cohort studies involved LTT alone. Different adjunctive training modalities were included: mannequins in 6 studies, cadavers in 2, computer simulation in 1, video presentations in 2 and wound moulage scenarios in 1 . The overall methodological quality was moderate as per the Newcastle-Ottawa score (mean $6.0 \pm 0$, possible range 1-9). The 2 RCTs did not demonstrate adequate random sequence generation and allocation concealment.

Conclusion: There is limited evidence that other types of simulation are better than LTT. Data on training effects of LTT versus other simulations on outcomes are lacking.

Contexte : Les préoccupations croissantes du public envers le bien-être des animaux, le perfectionnement des dispositifs de simulation informatisés et les contraintes budgétaires ont remis en question la formation sur tissus vivant (FTV) pour l'acquisition des compétences en traumatologie. Par conséquent, d'autres méthodes de simulation ont remplacé la FTV, par exemple, le cours ATLS (Advanced Trauma Life Support - Cours avancé de réanimation des polytraumatisés). Étant donné l'absence de conclusions claires dans la littérature, nous avons procédé à une revue systématique afin de comparer la valeur de la FTV seule à celle d'autres méthodes de simulation en traumatologie.

Méthodes : Nous avons procédé à une revue systématique de la littérature, plus particulièrement des études d'observation et des essais randomisés et contrôlés (ERC) portant exclusivement sur la FTV en traumatologie ou en comparaison avec d'autres méthodes de simulation. De manière indépendante et dupliquée, nous avons sélectionné les études à inclure et nous en avons extrait les données. Nous avons évalué la qualité et le risque de biais.

Résultats : Douze études répondaient aux critères d'inclusion : 2 ERC et 10 études de cohorte prospectives. Huit et 4 études ont été effectuées dans des contextes militaires et civils, respectivement. Des porcs anesthésiés ont été utilisés pour 8 études et des chèvres pour une étude. Les études de cohorte ne concernaient que la FTV. Les différentes modalités de formation complémentaires incluaient : mannequins dans 6 études, cadavres dans 2 études, simulation par ordinateur dans 1 étude, présentations vidéo dans 2 études et scénarios de moulage de plaies dans 1 étude. La qualité méthodologique globale s'est révélée modérée selon le score Newcastle-Ottawa (moyenne 6,0 \pm 0 , éventail de valeurs possibles 1-9). Les 2 ERC ne disposaient pas de séquences aléatoires adéquates et l'attribution des traitement n'y était pas effectuée à l'insu.

Conclusion : Les preuves dont on dispose pour déterminer si d'autres types de simulation sont préférables à la FTV sont limitées. On manque de données comparatives concernant les effets de la FTV sur l'issue des interventions par rapport à d'autres types de simulations. 
$\mathrm{n}$ both the military and civilian settings, medical care providers are trained in trauma care using a combination of approaches. For example, background knowledge and theory are often provided through didactic lectures, while practical and resuscitation skills are often based on a simulation-based platform, including computer simulation, task trainers and mannequins (human patient simulation [HPS]). Finally, live tissue training (LTT) is a form of simulation used more consistently for teaching and practising more complex surgical procedures. ${ }^{1}$

Live tissue training in medical education has been facing increasing scrutiny owing to the increased focus on animal welfare and by the rapid improvements in medical simulation technology. ${ }^{2}$ In the United States, the Department of Defence has closed a number of animal laboratories, including those that used dogs for ballistic wound management training and monkeys in chemical weapons casualty management exercises. ${ }^{3}$ In the civilian setting, the American College of Surgeons' Advanced Trauma Life Support (ATLS) course has largely moved away from LTT to simulation-based training. ${ }^{1}$

Currently, simulation and LTT are still both used in trauma care skills acquisition. However, it remains unclear whether simulation can completely replace LTT or whether there still remains a role for LTT in trauma education. To better explore this question, we conducted a systematic review to determine the value of LTT alone and in comparison to other simulation training methods in trauma care.

\section{Methods}

We conducted our systematic review in accordance with Preferred Reporting Items for Systematic Reviews and Meta-analyses (PRISMA) guidelines. ${ }^{4}$

\section{Information sources and search technique}

With the assistance of an experienced librarian, we searched MEDLINE (1947 to March 2014), EMBASE (1946 to March 2014) and the Cochrane Central Register of Controlled Trials (up to March 2014) using the keywords "live tissue training AND trauma," "simulation AND trauma," or "simulation AND surgical training." Citations of relevant full-text reports were manually searched for additional studies. We did not impose language restrictions. Details of the search strategy are in Appendix 1.

\section{Eligibility criteria and study selection}

Studies were eligible for inclusion in the systematic review if they were observational studies or randomized controlled trials (RCTs) and if they addressed trauma skills acquisition with LTT exclusively or if they addressed trauma skills acquisition with LTT compared with any other method of training in trauma. We excluded studies that addressed only other types of simulation (not LTT), that involved LTT not performed in trauma, that used animals for experiments rather than training, and that were case reports or case series. Two of us (L.T.D and S.V.) independently reviewed the abstracts of all studies. Agreement between reviewers was assessed using Cohen's ${ }^{5}{ }^{5}$ In case of disagreement, consensus was reached by discussion with a third author (B.N.J.). Fulltext versions of the selected studies were retrieved, and we contacted the corresponding authors for further information if necessary.

\section{Data abstraction and analysis}

Data were extracted from original studies. We abstracted data on study objective, setting and design; participant selection; types of LTT and other methods of simulation; intervention; types of evaluation pre- and posttraining; and outcomes. Two of us (L.T.D. and S.V.) independently assessed the risk of bias for cohort studies based on the Newcastle-Ottawa scale ${ }^{6}$ and for RCTs based on the Cochrane Collaboration tool. ${ }^{7}$ Our principal objective was to determine whether LTT is better than any other method of simulation for trauma care skills acquisition. Owing to clinical and methodological heterogeneity among studies, we anticipated reporting results qualitatively instead of conducting a meta-analysis.

\section{Results}

Our initial search strategy identified 385 potentially relevant studies. After evaluating 51 full-text manuscripts, we determined that 12 studies satisfied our inclusion criteria (Fig. 1). There was excellent agreement between the reviewers for study inclusion $(\kappa=0.84)$.

\section{Study characteristics}

Of the 12 studies included in our review (Table 1), 10 publications ${ }^{8-11,13-17,19}$ were prospective observational cohort studies and $2^{12,18}$ were RCTs. Eight studies ${ }^{8,11,13,15-19}$ were performed in the military setting and 4 studies $^{9,10,12,14}$ in the civilian setting. Anesthetized swine were used in 8 studies $^{9-14,16,18}$ and goats ${ }^{15}$ in 1 study; the remaining 3 studies $^{8,17,19}$ did not report the type of live tissue used for training.

Training consisted of LTT with no direct comparison to other simulations in 10 studies. $^{8-11,13-17,19}$ In those studies, only pre- and posttraining evaluations were performed, and LTT was conducted concurrently with other simulation methods. The remaining 2 studies ${ }^{12,18}$ compared LTT to other training modalities. Different adjunctive training modalities were included: 6 studies ${ }^{12,15-19}$ used HPS, $2^{18,19}$ used cadavers, $1^{12}$ used computer simulation, $2^{8,10}$ used video presentations and $1^{19}$ used wound moulage with human volunteers. 


\section{Participant characteristics}

The 12 studies included 2655 trainees. The sample size across studies varied markedly (range 15-1317, median 100, interquartile range [IQR] 47-184). In both civilian and military settings the trainees included nonmedical personnel, noncommissioned officers, medical technicians, dentists, nurses, nurse anesthetists and physician assistants. Among the participants in the medical field were trainees, such as third-year medical students, and junior and more experienced physicians from several specialties (e.g., general surgery, trauma surgery, anesthesiology, emergency medicine, family medicine and gynecology). Ten studies ${ }^{8-13,16-19}$ reported the level of participating trainees. The 2 randomized trials were conducted with third-year medical students ${ }^{12}$ and with air force volunteers with no practical trauma experience. ${ }^{18}$

\section{Methodological quality}

The qualitative synthesis of the cohort studies was performed using the Newcastle-Ottawa $\operatorname{score}^{6}$ (Table 2). The score defines participant groups in cohort studies as comparable in either the design or analysis when the effect of the exposure is adjusted for confounders. The overall methodological quality was moderate ( $n=10$ studies), with a mean score of $6.0 \pm 0$ (possible range 1-9).

There was a wide variation in the experience of the trainees, and the cohorts were representative of the overall population in the field of trauma training. Only 1 study ${ }^{11}$ had participants with similar level of experience. The 10 prospective cohort studies were not controlled with other training modalities for trauma skills acquisition. All cohort studies involved pretraining questionnaires (used as control) and posttraining questionnaires. All studies had adequate follow-up to allow outcomes to occur, and no loss to follow-up was reported.

We used the Cochrane Collaboration tool ${ }^{7}$ to assess risk of 5 bias domains in the 2 RCTs (Table 3). Sample size was not calculated in these studies. They did not demonstrate adequate random sequence generation and allocation concealment. Outcome assessors were blinded in both RCTs. Because the study durations were generally short, neither study had losses to follow-up. These 2 RCTs did not report missing data. No selective reporting or baseline imbalance of participants was detected in either study.

\section{Presimulation phase}

Studies included various forms of adjunctive education approaches. A large variety of didactic lectures were administered in 11 studies. ${ }^{8,10-19}$ Case study presentations, ${ }^{14-16}$ microteachings, ${ }^{8}$ video presentations, ${ }^{8,10}$ educational CD-ROMs, ${ }^{9,10}$ triage scenarios ${ }^{13,15,16}$ and discussions on case simulations ${ }^{14-16,19}$ were administered mostly in the presimulation phase.

\section{Interventions}

\section{Cohort studies}

All prospective cohort studies ${ }^{8-11,13-17,19}$ used LTT alone or LTT in combination with some other form of simulation, but they made no comparisons between methods and, consequently, had no control groups. Training modalities in this group varied considerably. In 1 study, ${ }^{11}$ anesthetized swine were subjected to penetrating trauma to the abdomen and legs. The ATLS principles were applied initially, and subsequently the swine were transferred to a field hospital and surgical procedures were performed. In another study ${ }^{8}$ involving the Combat Trauma Life Support (CTLS) course, there was no mention about the type of LTT used and the procedures performed during training. In 4 studies ${ }^{9,10,13,14}$ more advanced surgical training was conducted, with repair of penetrating injures to the chest and abdomen; surgical repair of the heart, solid organs, hollow viscera and vessels; and management of injures to the extremities. These studies include the current Definitive Surgical Trauma Care (DSTC) course ${ }^{9}$ and the Advanced Trauma Operative Management (ATOM) course..$^{10}$ Finally, King and colleagues ${ }^{13}$ studied advanced training in penetrating neck injuries (repair of carotid and jugular lesions), transmediastinal gunshot wounds (GSW) and thoracoabdominal penetrating wounds performed in anesthetized swine.

Six studies ${ }^{12,15-19}$ included mannequins as adjuncts to LTT. In the 2 studies conducted by Sohn and colleagues ${ }^{15,16}$ in the military setting, HPS was used for initial assessment for endotracheal intubation, surgical airway, venous and interosseus accesses, tube thoracostomy, tourniquet, triage and resuscitation scenarios. In the LTT portion, several other more complex procedures were performed, including amputation, management of evisceration and mesenteric bleeding, physiologic monitoring, moulage casualties and surgical simulation combined with a real time field-training event. Finally, 1 study ${ }^{17}$ also used HPS and LTT in a cohort of trainees, but delegated some procedures more appropriate to be performed on the live tissue section of the training (e.g., management of evisceration, local hemostasis, dissection for venous access).

\section{Randomized controlled trials}

The 2 randomized controlled trials evaluated training across 3 different procedures. In the study by Bowyer and colleagues, ${ }^{12}$ students were randomized to either LTT or a haptic simulator for teaching diagnostic peritoneal lavage (DPL). Both groups of 20 medical students were then asked to perform DPL in the HPS and were scored on this performance as the outcome measure. Hall ${ }^{18}$ administered didactic lectures and a basic suturing course and randomized participants to perform cricothyroidotomy and tube thoracostomy using HPS and LTT; participants performed both procedures in human cadavers in sequence. 


\section{Outcome measurements}

Not all studies evaluated their results objectively, and different measurements were performed across studies. Nine studies ${ }^{8-13,15-17}$ used multiple-choice questionnaires and Likert scales before and after the training process, where knowledge, self-confidence, self-efficacy and expertise were assessed. Details on surgical technique were evaluated in 4 studies. ${ }^{10,12,18,19}$ Sohn and colleagues, ${ }^{15}$ in a prospective cohort, conducted a comprehensive evaluation of the degree of learning on technical skills, understanding of clinical aspects, identification of priorities and repair of the induced lesions in a real time field-training event. Four studies ${ }^{13,15-17}$ included a meeting for debriefing of performance at the end of the training process. Finally, in 2 studies, ${ }^{13,15}$ an objective written metric questionnaire was completed during the training by staff members, and feedback was given to participants.

\section{Outcomes}

\section{Cohort studies}

Studies that used pre- and posttest questionnaires showed significant improvement posttraining. In general, posttest questionnaires demonstrated improvement in knowledge, self-perceived confidence and self-awareness. ${ }^{8-12,14-17,19}$ Participants also felt that the principles taught during training were appropriate and necessary to subsequently be applied in real life on a patient. ${ }^{13,15,16}$ In 1 study $^{8}$ involving the CTLS course, posttest scores increased from $65 \%$ to $76.6 \%$ $(p<0.001)$ after LTT. In the DSTC course, where training in thoracic and abdominal lesions were evaluated, Jacobs and colleagues ${ }^{9}$ reported that posttest score improvement was greater in less experienced general surgery trainees than in fellows and staff surgeons. In another study involving the ATOM course (which uses anesthetized swine for the training of general surgeons, trauma fellows and general surgery residents), the same group ${ }^{10}$ demonstrated that the

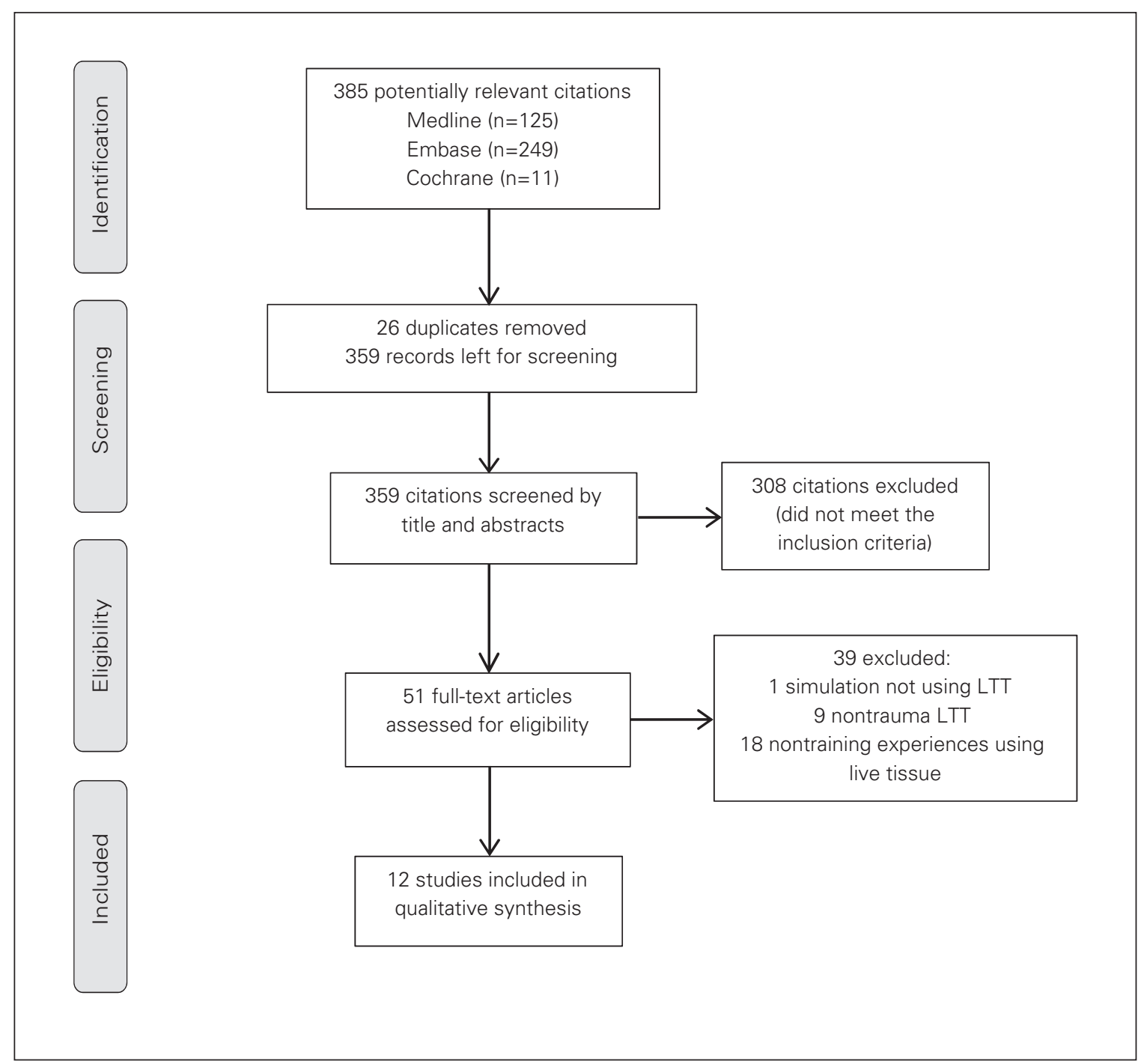

Fig. 1. Flow diagram of the screening process. LTT = live tissue training. 
knowledge of expert surgeons and trauma fellows improved considerably ( $p=0.016$ and $p=0.005$, respectively). Gaarder and colleagues ${ }^{11}$ assessed teams of surgeons being trained in peripheral lesions and damage control laparotomy in anesthetized swine. They reported an improvement of $43 \%$ and $60 \%$ of the overall score and of the score of younger general surgeons, respectively. King and colleagues ${ }^{13}$ evaluated the surgical aspects of trauma management and concluded that the trainees were able to avoid $20 \%$ of preventable deaths. However, they concluded that additional experience to quantify the training impact of the type of exercise as well as the validity of the used metrics were still required.

In a study by Sohn and colleagues ${ }^{15}$ in which HPS and LTT were used concurrently during training exercises, LTT scored higher than HPS (1.48 v. $2.55, p<0.01)$. Some limitations of the study, such as quality of data, may have affected inferences. Rubiano and colleagues ${ }^{17}$ reported that all participants trained using HPS and LTT demonstrated complete knowledge in the final evaluation. Finally, in a more recent study ${ }^{19}$ where surgical skills were assessed in LTT and mechanical HPS, participants found that clinical shadowing was less valuable than both methods of surgical skills acquisition.

\section{Randomized controlled trials}

The 2 RCTs involved a small number of participants $(n=64)$; had different types of interventions (DPL, tube thoracostomy, cricothyroidotomy) and simulation controls; and assessed knowledge, efficacy, competence, awareness and technical skills in the 3 training modalities. Bowyer and colleagues ${ }^{12}$ conducted a study with medical students, randomizing DPL in a haptic simulator and in anesthetized swine. Subsequently, both groups performed DPL in an HPS model. There was a significant improvement from baseline knowledge in both groups, yet more improvement in the graphical interface simulation group in terms of site selection $(p<$ $0.001)$ and technique $(p=0.002)$ than those who trained on swine. In a study conducted with air force volunteers with no

\begin{tabular}{|c|c|c|c|c|c|c|c|}
\hline Study & Design & Setting & Participants & $N$ & Interventions & Evaluations & $\begin{array}{l}\text { Comparator } \\
\text { group }\end{array}$ \\
\hline $\begin{array}{l}\text { Kluger } \\
\text { et al. }{ }^{8}\end{array}$ & $\begin{array}{l}\text { Prospective } \\
\text { cohort }\end{array}$ & Military & $\begin{array}{c}\text { Students of CTLS course } \\
\text { Military physicians, dissimilar } \\
\text { experience, different training levels }\end{array}$ & 77 & $\begin{array}{l}1 \text { - Videos, wound moulage } \\
2 \text { - LTT (details not reported) }\end{array}$ & $\begin{array}{c}\text { Pre- and } \\
\text { posttraining }\end{array}$ & No control \\
\hline $\begin{array}{l}\text { Jacobs } \\
\text { et al. }{ }^{9}\end{array}$ & $\begin{array}{l}\text { Prospective } \\
\text { cohort }\end{array}$ & Civilian & $\begin{array}{c}\text { Students of DSTC course } \\
\text { PGY-4, PGY-5, fellows and junior } \\
\text { attendings }\end{array}$ & 15 & $\begin{array}{l}1 \text { - Interactive CD-ROM } \\
2 \text { - Anesthetized swine }\end{array}$ & $\begin{array}{l}\text { Pre- and } \\
\text { posttraining }\end{array}$ & No control \\
\hline $\begin{array}{l}\text { Jacobs } \\
\text { et al. }{ }^{10}\end{array}$ & $\begin{array}{l}\text { Prospective } \\
\text { cohort }\end{array}$ & Civilian & $\begin{array}{l}\text { Students of ATOM course } \\
\text { Traumatologists, general surgeons, } \\
\text { trauma fellows, PGY-4 and } 5 \\
\text { general surgery residents }\end{array}$ & 50 & 1 - Anesthetized swine & $\begin{array}{c}\text { Pre- and } \\
\text { posttraining }\end{array}$ & No control \\
\hline $\begin{array}{l}\text { Gaarder } \\
\text { et al. }{ }^{11}\end{array}$ & $\begin{array}{l}\text { Prospective } \\
\text { cohort }\end{array}$ & Military & $\begin{array}{c}67 \%(n=95) \text { general surgeons } \\
>4 y \text { of experience } \\
33 \%(n=49)<4 y \text { of experience }\end{array}$ & 144 & $\begin{array}{l}1 \text { - Anesthetized swine } \\
\text { inflicted by a GSW to the } \\
\text { abdomen and to the thigh }\end{array}$ & $\begin{array}{c}\text { Pre- and } \\
\text { posttraining }\end{array}$ & No control \\
\hline $\begin{array}{l}\text { Bowyer } \\
\text { et al. }{ }^{12}\end{array}$ & $\begin{array}{l}\text { Randomized } \\
\text { controlled } \\
\text { trial }\end{array}$ & Civilian & $\begin{array}{l}\text { Third-year medical students } \\
\text { No expertise in DPL }\end{array}$ & 40 & $\begin{array}{l}1 \text { - Graphical user interface } \\
\text { simulator } \\
2 \text { - Anesthetized swine } \\
3 \text { - HPS }\end{array}$ & $\begin{array}{l}\text { Pre- and } \\
\text { posttraining }\end{array}$ & $\begin{array}{l}\text { Computer } \\
\text { simulator }\end{array}$ \\
\hline $\begin{array}{l}\text { King } \\
\text { et al. }{ }^{13}\end{array}$ & $\begin{array}{l}\text { Prospective } \\
\text { cohort }\end{array}$ & Military & $\begin{array}{c}\text { General and orthopedic surgeons, } \\
\text { nurses, OR technicians, ED } \\
\text { technicians }\end{array}$ & 304 & 1 -Anesthetized swine & $\begin{array}{c}\text { Pre- and } \\
\text { posttraining }\end{array}$ & No control \\
\hline $\begin{array}{l}\text { Tugnoli } \\
\text { et al. }{ }^{14}\end{array}$ & $\begin{array}{l}\text { Prospective } \\
\text { cohort }\end{array}$ & Civilian & $\begin{array}{l}\text { Residents and general surgeons } \\
\text { Level of training not reported }\end{array}$ & 126 & 1 - Anesthetized swine & Posttraining & No control \\
\hline $\begin{array}{l}\text { Sohn } \\
\text { et al. }{ }^{15}\end{array}$ & $\begin{array}{l}\text { Prospective } \\
\text { cohort }\end{array}$ & Military & $\begin{array}{l}\text { Soldiers deploying to combat } \\
\text { operations } \\
\text { Level of training not reported }\end{array}$ & 1317 & $\begin{array}{c}1-\text { HPS } \\
2-\text { Anesthetized goats }\end{array}$ & $\begin{array}{l}\text { Pre- and } \\
\text { posttraining }\end{array}$ & No control \\
\hline $\begin{array}{l}\text { Sohn } \\
\text { et al. }{ }^{16}\end{array}$ & $\begin{array}{l}\text { Prospective } \\
\text { cohort }\end{array}$ & Military & $\begin{array}{c}\text { Non-surgical graduating residents } \\
\text { (internists, gynecologists and } \\
\text { obstetricians) }\end{array}$ & 60 & $\begin{array}{c}1-\text { HPS } \\
2-\text { Anesthetized swine }\end{array}$ & $\begin{array}{c}\text { Pre- and } \\
\text { posttraining }\end{array}$ & No control \\
\hline $\begin{array}{l}\text { Rubiano } \\
\text { et al. }{ }^{17}\end{array}$ & $\begin{array}{l}\text { Prospective } \\
\text { cohort }\end{array}$ & Military & $\begin{array}{l}\text { Combat nurses, MEDTAC course } \\
\text { in Colombia } \\
\text { Level of training not reported }\end{array}$ & 374 & $\begin{array}{c}1-\text { HPS } \\
2-\text { LTT } \\
\text { (both not described in details) }\end{array}$ & $\begin{array}{l}\text { Pre- and } \\
\text { posttraining }\end{array}$ & No control \\
\hline $\mathrm{Hall}^{18}$ & $\begin{array}{l}\text { Randomized } \\
\text { controlled } \\
\text { trial }\end{array}$ & Military & $\begin{array}{l}\text { Air force volunteers with no prior } \\
\text { medical training }\end{array}$ & 24 & $\begin{array}{c}1-\text { HPS } \\
2-\text { Anesthetized swine }\end{array}$ & Posttraining & HPS \\
\hline $\begin{array}{l}\text { McLaughlin } \\
\text { et al. }{ }^{19}\end{array}$ & $\begin{array}{l}\text { Prospective } \\
\text { cohort }\end{array}$ & Military & $\begin{array}{l}\text { Physicians (general practitioners } \\
\text { and surgeons), nurses, physicians } \\
\text { assistants and medical technicians } \\
\text { Level of training not reported }\end{array}$ & 124 & $\begin{array}{c}1 \text { - HPS } \\
2 \text { - LTT (no details reported) } \\
\text { 3-Cadaveric models }\end{array}$ & Posttraining & No control \\
\hline
\end{tabular}


prior medical training, Hall ${ }^{18}$ conducted training in cricothyroidotomy and tube thoracostomy, randomizing LTT (anesthetized swine) and HPS. In sequence, the 2 groups performed both procedures in human cadavers. There was no statistical difference in average completion time for the procedures in both groups ( $p=0.74$ and $p=0.32$, respectively). Confidence was higher overall in the LTT group, but no statistical difference was found $(p=0.42)$. The success rates of cricothyroidotomy and chest tube placement were higher in the animal group, but with no statistical significance $(p=0.67$ and $p=0.99$, respectively). There was no difference in outcomes or confidence for both procedures in both groups.

\section{Discussion}

Our systematic review yielded 12 studies addressing LTT alone or concurrently with other forms of simulation in trauma, 2 of which were RCTs. The 10 prospective cohort studies conducted pre- and posttraining evaluations but did not directly compare LTT with other methods of trauma skills acquisition. The objectives varied, ranging from general (evaluation of an entire field exercise) to specific (evaluation of the performance on a specific surgical procedure). Our overall conclusion is that simulation, independent of its modalities, improves knowledge, efficacy, competency, surgical skills and awareness. We did not identify a body of evidence robust enough to conclude whether LTT is better than other simulation methods. Small sample size, different levels of training participants, different forms of interventions and simulators, absence of controls in the majority of studies and different outcomes assessed are factors impeding a more reliable analysis and conclusion. Studies did not include reliability or validity data, and a large number of them used different types of participant surveys to evaluate self-reported operative confidence or course efficacy. An additional limitation is the potential for assessor bias, as most prospective cohort studies involved 1 or more evaluators assessing performance, and these studies did not provide their curricular information.

Both RCTs had small sample sizes. There were only 64 participants in total across both RCTs, which influenced the detection of differences among forms of training. There were multiple and confounding comparisons. The power to

Table 2. Newcastle-Ottawa score ${ }^{6}$ for the cohort studies included in the systematic review

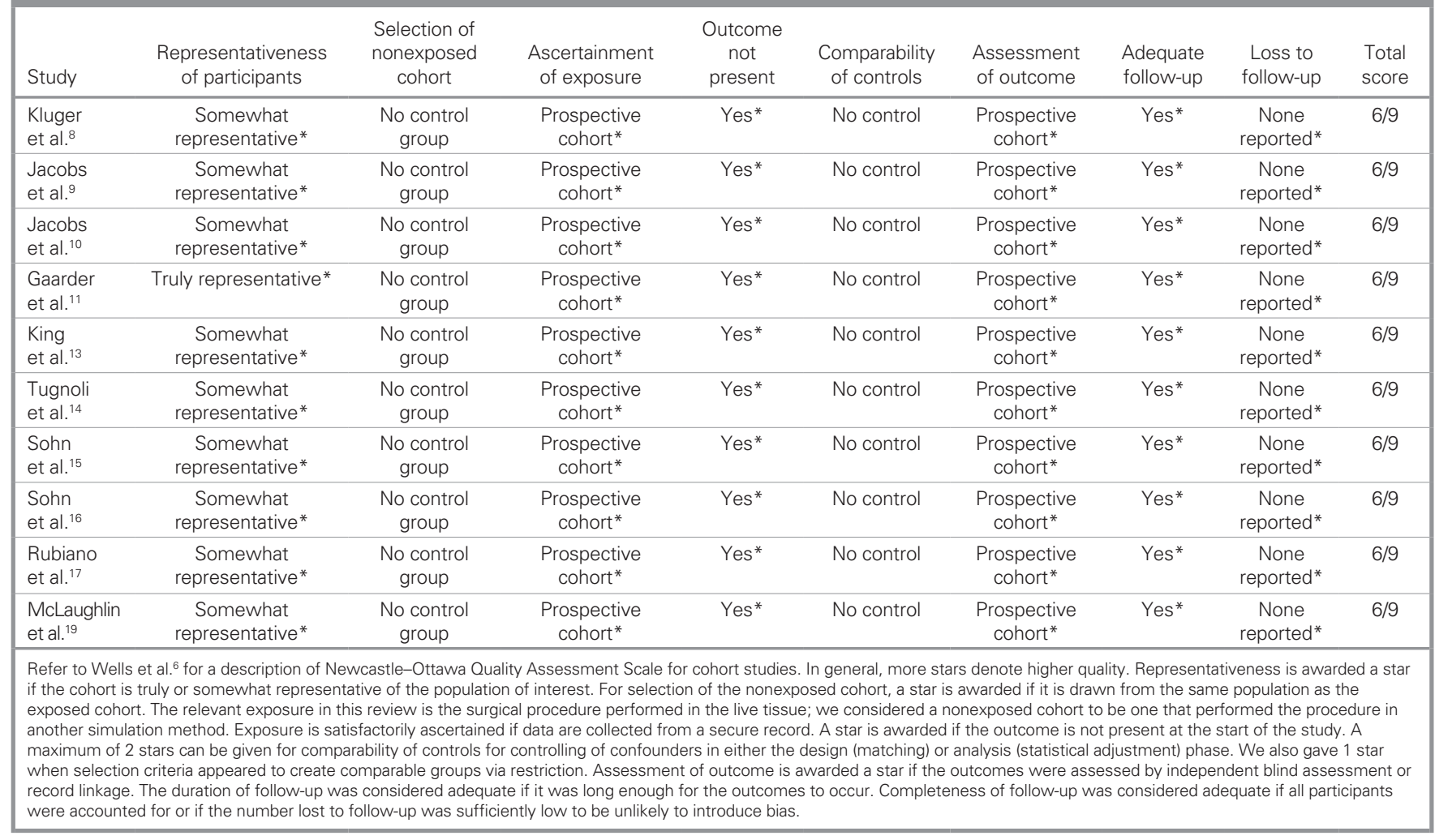

Table 3. Risk of bias assessment for randomized controlled trials based on the Cochrane Collaboration tool ${ }^{7}$

\begin{tabular}{|c|c|c|c|c|c|c|c|}
\hline Study & $\begin{array}{l}\text { Random } \\
\text { sequence } \\
\text { generation }\end{array}$ & $\begin{array}{c}\text { Allocation } \\
\text { concealment }\end{array}$ & $\begin{array}{l}\text { Blinding of } \\
\text { participants and } \\
\text { researches }\end{array}$ & $\begin{array}{l}\text { Incomplete } \\
\text { outcome data }\end{array}$ & $\begin{array}{l}\text { Selective } \\
\text { reporting }\end{array}$ & Baseline imbalance & Sample size \\
\hline Bowyer et al. ${ }^{12}$ & High risk & High risk & Low risk & Low risk & Low risk & Low risk & Not calculated \\
\hline $\mathrm{Hall}^{18}$ & High risk & High risk & Low risk & Low risk & Low risk & Low risk & Not calculated \\
\hline
\end{tabular}


detect any differences was further diluted by different comparisons, both within and between studies. The comparisons may have also been confounded by factors such as mentoring, which could have swamped any effect of simulation. The component tasks varied considerably between studies. Comparators were not standardized. In all studies, superiority of simulation and LTT was found when any type of simulation was applied compared with no simulation, but there was no standardization for comparison of LTT with another simulation method. The surgical simulations may not have been intensive or long enough to show an effect on training. While some simulator interventions were very brief, a practice effect with longer simulator exposure was not generally evident. However, most simulator interventions showed significant improvements pre- and postintervention. Outcome assessors in the RCTs were blinded to group, but the participants could not be blinded.

\section{Limitations}

To our knowledge, our study is the first to summarize the literature concerning the use of LTT in trauma alone or compared with other forms of simulation, but robust conclusions are limited by the overall low methodological quality of the included studies. We used a comprehensive search strategy to exhaustively identify any relevant studies in the published literature. We found only 2 small experimental studies and the quality of the observational analytic cohorts is limited. Included studies were heterogeneous with respect to participants, interventions, controls, measurements and outcomes, limiting clinical interpretation and generalizability. Major limitations of this review are related to the limitations of the included studies. Better-designed and larger cohort studies and RCTs are lacking.

\section{Unanswered questions and future research}

The current body of literature does not answer the persistent question of which method provides the most effective training and improvement in self-confidence for physicians worldwide. In a study ${ }^{20}$ in the military setting, we assessed the association of experience using different training modalities, including LTT, with self-reported confidence in procedure performance. Advanced life support providers were sent a questionnaire regarding their experience with and self-confidence levels in performing endotracheal intubation, cricothyroidotomy, needle chest decompression, tube thoracostomy and intraosseous infusion. Selfconfidence levels in procedure performance were positively associated with experience gained from mannequins and from supervised and unsupervised application in patients. We were not able to demonstrate a clear benefit of an animal model in increasing self-confidence. A plateau was generally identified, indicating decreased benefit from the use of a particular training modality for a particular procedure.
A wide range of trauma training modalities exist, ${ }^{21}$ but each (including high-fidelity simulators) has limitations. Cherry and $\mathrm{Ali}^{21}$ commented on the realism and authenticity problems of using simulators and concluded that these challenges needed to be overcome. Human cadavers and HPS currently do not provide the ideal solution. Most patient simulators do not bleed. Those that do bleed do not respond in the same biological way that bleeding patients do in clinical practice. Therefore, complex surgical skills are usually taught on live tissue models, because dissection and bleeding is not properly simulated in any other models. Likewise, research in bleeding and hemorrhage control is never conducted using mannequins. Mannequins cannot simulate bleeding accurately. An example of the importance of using live tissue is testing new hemostatic dressings, ${ }^{22-32}$ which would be impossible to perform in mannequins or with virtual simulation.

Although human cadavers are advantageous because of their anatomic similarity, dead tissue does not respond to surgical procedures and other interventions in the same way that living patients do in everyday trauma practice. Different anatomy is a disadvantage in live animals. Clearly, dogs and goats do not have anatomy identical to humans, which is demonstrated in the study by McCarthy and colleagues. ${ }^{33}$ In that study, necks with attempted cricothyroidotomies were inspected and mapped, and the authors found that $30.2 \%$ of cricothyroidotomies in the canine models were misplaced. Cricothyroidotomy placement in human cadavers was correct in $96.4 \%$.

We agree that supervised hands-on experience in the management of trauma patients would be the best solution; however, this does not take into account the ongoing lack of supervision in many hospitals nor does it account for the reduced exposure to operative trauma being experienced by many trainees worldwide. On the other hand, there are a number of simulators available for generic training which, although improving in their ability to provide useful training, do not yet have the full capability of encompassing all aspects of live tissue training. ${ }^{34}$ For this reason, the American College of Surgeons "supports the use and humane care and treatment of laboratory animals in research, education, teaching, and product safety testing in accordance with applicable local, state, and federal animal welfare laws." The American College of Surgeons comments that "wherever feasible, alternatives to the use of live animals should be developed and employed" but "believes that now and in the foreseeable future it is not possible to completely replace the use of animals and that the study of whole living organisms, tissues, and cells is an indispensable element of biomedical research, education, and teaching." 35

Understandably, the primary argument against the use of LTT encompasses highly emotive ethical and moral objections to the harming of live animals. These cannot be, nor should they be, ignored. However, to suggest that there is evidence to say that the use of currently available simulators is equivalent or superior to LTT for all trauma 
procedures and skills is erroneous. The development of more realistic simulators to address these issues needs to progress in order that LTT can be discontinued.

While simulators other than LTT have been developed and have already replaced some use of live animals in many areas of trauma training, there is still a need for development of clinically relevant simulation models. Furthermore, such models will need to be validated by studies that use assessment tools that reliably address skills acquisition, the transfer of skills to the operating room and real trauma environments, and the retention of such skills over time. While there may be compelling reasons to reduce reliance on patients, cadavers and animals for trauma training, none of the methods of simulated training has yet been shown to be better than these forms of training. Adequately powered, well-designed and unconfounded RCTs (preferably multicentre with similar protocols) are needed, and outcome assessors need to be blinded. Outcomes need to be tested in actual operative circumstances (or on validated systems). In particular, model simulation needs to be further tested against computer simulation. Studies of cost comparisons are also needed. The RCTs included in our analysis dealt exclusively with technical skills, although other skills, such as cognitive and communication skills, are clearly integral parts of the trauma training process.

\section{Conclusion}

Our systematic review demonstrated limited observational and experimental evidence on the use of LTT in trauma. This review will enable clinicians to better appreciate the deficiencies identified in the literature, and enable investigators to design more appropriate trials in the future. The existing literature helps clinicians to appreciate the potential impact of the use of LTT in trauma. However, adequately powered and methodologically sound RCTs will be required to prove positive effects on outcomes.

Affiliations: From the Department of Surgery and Critical Care Medicine, Sunnybrook Health Sciences Centre, University of Toronto, Toronto, Ont. (da Luz, Nascimento, Tien, Kim, Nathens, Vlachos); and Trauma \& Combat Medicine Branch, Surgeon General Headquarters, Israel Defense Forces, Ramat Gan, Israel (Glassberg).

Competing interests: None declared.

Contributors: L. da Luz, A. Nathens and H. Tien designed the study. L. da Luz, B. Nascimento, S. Vlachos and M. Kim acquired the data, which L. da Luz and E. Glassberg analyzed. L. da Luz, S. Vlachos and M. Kim wrote the article, which all authors reviewed and approved for publication.

\section{References}

1. Matt Ritter E, Bowyer MW. Simulation for trauma and combat casualty care. Minim Invasive Ther Allied Technol 2005;14:224-34.

2. Gala SG, Goodman JR, Murphy MP, et al. Use of animals by NATO countries in military medical training exercises: an international survey. Mil Med 2012;177:907-10.
3. Reprieve from wound tests is ended for pigs and goats. New York Times Jan. 24, 1984. Available: www.nytimes.com/1984/01/24/us /reprieve-from-wound-tests-is-ended-for-pigs-and-goats.html (accessed 2015 May 1).

4. Moher D, Liberati A, Tetzlaff J, et al. Preferred reporting items for systematic reviews and meta-analyses: the PRISMA statement. Int 7 Surg 2010;8:336-41.

5. Cohen J. Weighted kappa: nominal scale agreement with provision for scaled disagreement or partial credit. Psychol Bull 1968;70:213-20.

6. Wells GA, Shea B, O'Connell D, et al. The Newcastle-Ottawa Scale (NOS) for assessing the quality of nonrandomised studies in metaanalyses. Ottawa Hospital Research Institute. Available: www.ohri.ca /programs/clinical_epidemiology/oxford.asp (accessed 2015 May 1).

7. Higgins JP, Altman DG, Gotzsche PC, et al. The Cochrane Collaboration's tool for assessing risk of bias in randomised trials. $B M 7$ 2011;343:d5928.

8. Kluger Y, Rivkind A, Donchin Y, et al. A novel approach to military combat trauma education. 7 Trauma 1991;31(4):564-569.

9. Jacobs LM, Lorenzo C, Brautigam RT. Definitive surgical trauma care live porcine session: a technique for training in trauma surgery. Conn Med 2001;65:265-8.

10. Jacobs LM, Burns KJ, Kaban JM, et al. Development and evaluation of the advanced trauma operative management course. 7 Trauma 2003;55:471-9.

11. Gaarder C, Naess PA, Buanes T, et al. Advanced surgical trauma care training with a live porcine model. Injury 2005;36:718-24.

12. Bowyer MW, Liu AV, Bonar JP. Validation of SimPL - a simulator for diagnostic peritoneal lavage training. Stud Health Technol Inform 2005;111:64-7.

13. King DR, Patel MB, Feinstein AJ, et al. Simulation training for a mass casualty incident: two-year experience at the army trauma training center. 7 Trauma 2006;61:943-8.

14. Tugnoli G, Ribaldi S, Casali M, et al. Initial evaluation of the "trauma surgery course". World F Emerg Surg 2006;1:5.

15. Sohn VY, Miller JP, Koeller CA, et al. From the combat medic to the forward surgical team: the Madigan model for improving trauma readiness of brigade combat teams fighting the global war on terror. 7 Surg Res 2007;138:25-31.

16. Sohn VY, Runser LA, Puntel RA, et al. Training physicians for combat casualty care on the modern battlefield. F Surg Educ 2007;64:199-203.

17. Rubiano AM, Sanchez AI, Guyette F, et al. Trauma care training for national police nurses in Colombia. Prehosp Emerg Care 2010;14:124-30.

18. Hall $\mathrm{AB}$. Randomized objective comparison of live tissue training versus simulators for emergency procedures. Am Surg 2011;77:561-5.

19. McLaughlin T, Hennecke P, Garraway NR, et al. A predeployment trauma team training course creates confidence in teamwork and clinical skills: a post-Afghanistan deployment validation study of Canadian forces healthcare personnel. F Trauma 2011;71(Suppl 1):S487-93.

20. Sergeev I, Lipsky AM, Ganor O, et al. Training modalities and selfconfidence building in performance of life saving procedures. Mil Med 2012;177:901-6.

21. Cherry RA, Ali J. Current concepts in simulation-based trauma education. 7 Trauma 2008;65:1186-93.

22. Pusateri AE, Modrow HE, Harris RA. Advanced hemostatic dressing development program: animal model selection criteria and results of a study of nine hemostatic dressings in a model of severe large venous hemorrhage and hepatic injury in swine. 7 Trauma 2003;55:518-26.

23. Alam HB, Chen Z, Jaskille A. Application of a zeolite hemostatic agent achieves $100 \%$ survival in a lethal model of complex groin injury in swine. 7 Trauma 2004;56:974-83.

24. Alam HB, Uy GB, Miller D, et al. Comparative analysis of hemostatic agents in a swine model of lethal groin injury. 7 Trauma 2003;54:1077-82.

25. Sondeen JL, Pusateri AE, Coppes VG, et al. Comparison of 10 different hemostatic dressings in an aortic injury. 7 Trauma 2003;54:280-5.

26. Ward KR, Tiba MH, Holbert WH, et al. Comparison of a new 
hemostatic agent to current combat hemostatic agents in a swine model of lethal extremity arterial hemorrhage. 7 Trauma 2007;63:276-83.

27. Acheson EM, Kheirabadi BS, Deguzman R, et al. Comparison of hemorrhage control agents applied to lethal extremity arterial hemorrhages in swine. 7 Trauma 2005;59:865-74.

28. Sohn VY, Eckert MJ, Martin MJ, et al. Efficacy of three topical hemostatic agents applied by medics in a lethal groin injury model. 7 Surg Res 2009;154:258-61.

29. Satterly S, Nelson D, Zwintscher N. Hemostasis in a noncompressible hemorrhage model: an end-user evaluation of hemostatic agents in a proximal arterial injury. 7 Surg Educ 2013;70:206-11.

30. Kheirabadi BS, Acheson EM, Deguzman R, et al. Hemostatic efficacy of two advanced dressings in an aortic hemorrhage model in swine. 7 Trauma 2005;59:25-34.

31. Ahuja N, Ostomel TA, Rhee P, et al. Testing of modified zeolite hemostatic dressings in a large animal model of lethal groin injury. 7 Trauma 2006;61:1312-20.

32. Kheirabadi BS, Acheson EM, Deguzman R, et al. The potential utility of fibrin sealant dressing in repair of vascular injury in swine. 7 Trauma 2007;62:94-103.

33. McCarthy MC, Ranzinger MR, Nolan DJ, et al. Accuracy of cricothyroidotomy performed in canine and human cadaver models during surgical skills training. 7 Am Coll Surg 2002;195:627-9.

34. Moore WA, Noonan AC. Using live tissue laboratories to promote clinical reasoning in doctor of physical therapy students. Adv Physiol Educ 2010;34:54-8.

35. Statement on the use of animals in research, education, and teaching. American College of Surgeons, Oct. 1, 2002. Available: www.facs.org /fellows_info/statements/st-10.html (accessed 2015 May 1).

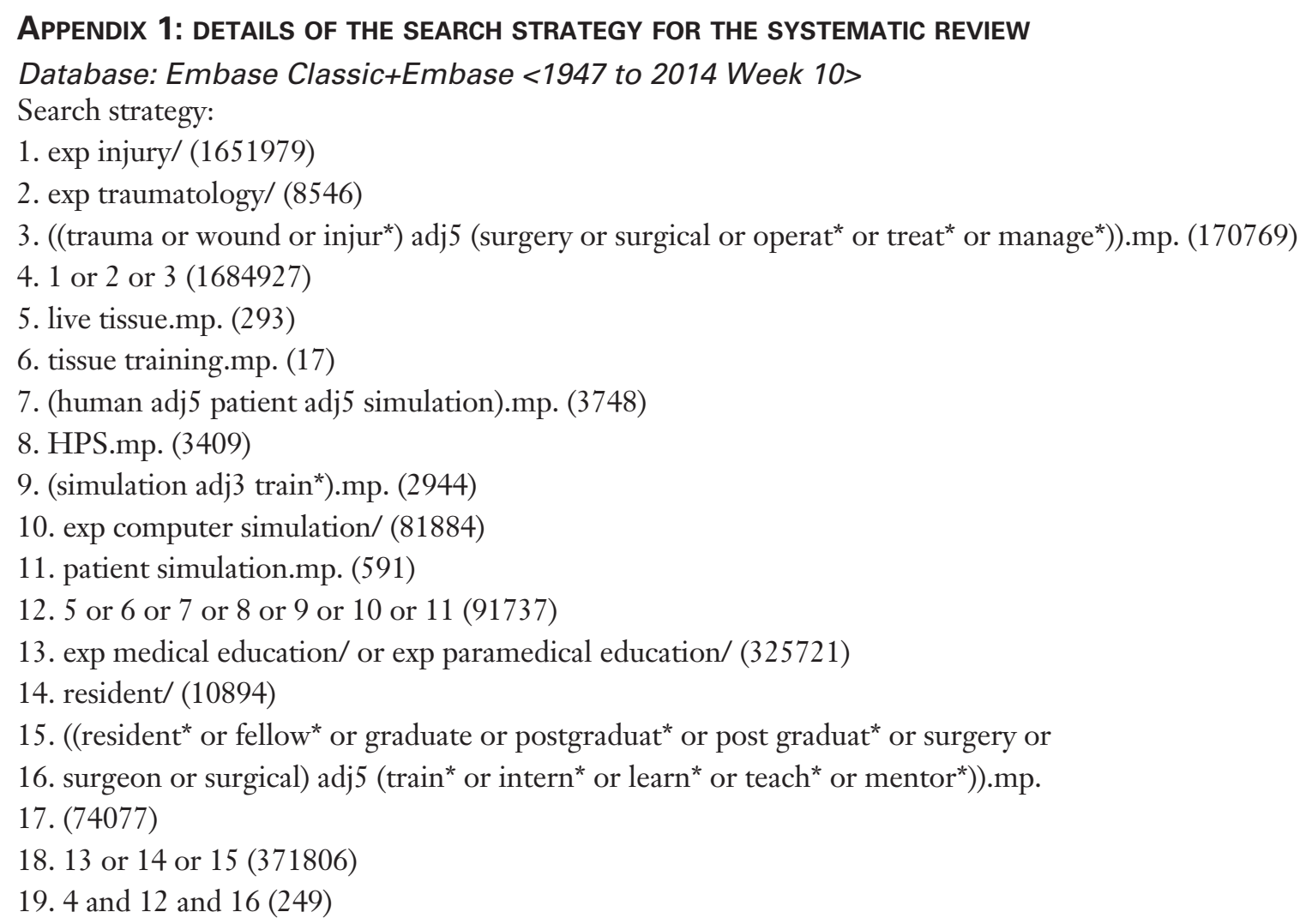

Database: EBM Reviews - Cochrane Central Register of Controlled Trials < January 2014> Search Strategy:

1. ((trauma or wound or injur*) adj5 (surgery or surgical or operat* or treat* or manage*)).mp. (8966)

2. live tissue.mp. (3)

3. tissue training.mp. (3)

4. (human adj5 patient adj5 simulation).mp. (10)

5. HPS.mp. (75)

6. (simulation adj3 train*).mp. (182)

7. computer simulation.mp. (1052)

8. patient simulation.mp. (258)

9. (resident* or fellow* or graduate or surgeon or postgraduat* or post graduat* or train* or intern* or learn* or education or mentor*).mp. (77945)

10. 101 and ( 2 or 3 or 4 or 5 or 6 or 7 or 8$)$ and $9(11)$ 


\section{APPENDIX 1 (CONTINUED FROM PREVIOUS PAGE)}

Database: Ovid MEDLINE(R) and Ovid OLDMEDLINE(R) <1946 to March Week 1 2014>

Search strategy:

1. exp "Wounds and Injuries"/ (696127)

2. exp Traumatology/ (2119)

3. ((trauma or wound or injur ${ }^{*}$ adj5 (surgery or surgical or operat ${ }^{*}$ or treat* or manage $\left.{ }^{*}\right)$.mp. (121574)

4.1 or 2 or $3(762472)$

5. live tissue.mp. (185)

6. tissue training.mp. (12)

7. (human adj5 patient adj5 simulation).mp. (99)

8. HPS.mp. (2296)

9. (simulation adj3 train*).mp. (1238)

10. exp Computer Simulation/ (146757)

11. patient simulation/ (3044)

12. 5 or 6 or 7 or 8 or 9 or 10 or $11(152436)$

13. exp education, professional/ (235463)

14. ((resident* or fellow* or graduate or postgraduat* or post graduat* or surgery or surgeon or surgical) adj5 (train* or intern* or learn* or teach* or mentor*)).mp. (33602)

15.13 or $14(252560)$

16. 4 and 12 and 15 (125) 